\section{Tirivavi Moyo}

Mr Tirivavi (T.) Moyo, PhD candidate, Department of Quantity Surveying, Nelson Mandela University, PO Box 77000 , Port Elizabeth, South Africa.

Phone: +263773054568,

E-mail: <tirivavimoyo@gmail. com>

\section{Gerrit Crafford}

Prof. Gerrit (G.) Crafford,

Associate Professor,

Department of Quantity Surveying, Nelson Mandela University, PO Box 77000 , Port Elizabeth, South Africa. Phone: +27 41504 2153, E-mail: <Gerrit.Crafford@ mandela.ac.za>

\section{Fidelis Emuze}

Prof. Fidelis (F.) Emuze,

Professor and Head,

Department of Built

Environment, Central University of Technology, Free State (CUT), Private Bag X20539, Bloemfontein, South Africa.

Phone: +27 515073089 ,

E-mail: <femuze@cut.ac.za>

DOI: http://dx.doi.

org/10.18820/24150487/as26i2.1

ISSN: 1023-0564

e-ISSN: 2415-0487

Acta Structilia 2019 26(2): 1-38

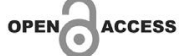

\section{Decent working conditions for improved construction workers' productivity on Zimbabwean building projects}

Peer reviewed and revised July 2019

Published December 2019

*The authors declared no conflict of interest for the article or title

\begin{abstract}
Construction labour productivity is declining, due to shortcomings in the Decent Work Agenda. This research seeks to determine decent working conditions that could improve the productivity of skilled and semi-skilled workers on construction sites in Zimbabwe. A quantitative research approach enabled a self-administered questionnaire survey among site management and workers from selected trades. The randomly selected respondents work for construction companies affiliated with the Construction Industry Federation of Zimbabwe database. The companies are based in Harare, Bulawayo, and Shurugwi. In addition, thirteen building project sites in the study area were purposively selected through the National Social Security Authority register. The results indicate that adequate work-related health and safety conditions and facilities were identified through ranking as the most significant decent work conditions under which improved labour productivity can be achieved. It is also notable that all the decent working conditions
\end{abstract}


assessed were deemed significant in terms of improving labour productivity. A Kruskal-Wallis test ascertained that there were no statistically significant differences due to the age, gender and experience of respondents. However, statistically significant differences were found due to the designation and educational levels of the respondents. The research study recommends that training on decent working conditions be undertaken and that accentuation of adequate decent working conditions on sites be encouraged. Adequate planning and financing for decent work conditions are also proffered.

Keywords: Construction, decent work, labour productivity, sustainable development, working conditions, Zimbabwe

\begin{abstract}
Abstrak
Die afname in die boukonstruksie se arbeidsproduktiwiteit is te wyte aan tekortkominge in die Voldoende Werksagenda. Hierdie navorsingstudie poog om behoorlike werksomstandighede te identifiseer wat arbeidsproduktiwiteit op boupersele sal kan verbeter. ' $n$ Kwantitatiewe navorsingsbenadering het 'n opname deur middel van 'n self-geadministreerde vraelys onder bouperseelen projekbestuurders asook ' $n$ vraelys wat voltooi is tydens ' $n$ onderhoud met geskoolde en ongeskoolde werknemers vit geselekteerde ambagte moontlik gemaak. Die geselekteerde ambagte is beperk tot baksteen- en bloklegging, timmer- en skrynwerk asook verfwerk, aangesien hierdie die mees bevolkte ambagte is asook kritiese padaktiwiteite. Die deelnemers aan die opname is geaffilieerd aan boumaatskappye wat in Harare, Bulawayo en Shurugwi in Zimbabwe gebaseer is. Hulle is lukraak van die databasis van die Konstruksiebedryf Federasie van Zimbabwe geselekteer. Daarbenewens is dertien bouprojekpersele doelbewus uitgekies deur middel van die register van die Nasionale Maatskaplike Sekuriteitsinstansie. Die uitslae dui daarop dat voldoende gesondheids- en veiligheidsmaatreëls en fasiliteite geïdentifiseer is as die beduidendste behoorlike werksomstandighede waaronder verbeterde arbeidsproduktiwiteit bereik kan word. Dit is ook opmerklik dat al die geskikte werksomstandighede wat in die navorsing geëvalveer is, beduidend is met betrekking tot die verbetering van arbeidsproduktiwiteit. 'n Kruskal-Wallis-toets het vasgestel dat daar geen statisties beduidende verskille was as gevolg van die verskille in ouderdom, geslag of ondervinding nie. Nietemin is daar statisties beduidende verskille gevind as gevolg van die beroep en onderwysvlak van die respondente. Die navorsingstudie beveel aan dat ingryping behoort plaas te vind met verwysing na opleiding met betrekking tot geskikte werksomstandighede en die beklemtoning van geskikte werksomstandighede op boupersele met gepaardgaande beplanning en vitvoering van aktiwiteite. Konstruksiewerknemers behoort ook aan te dring op geskikte werksomstandighede in die omgewing van boupersele. Voorts ondersteun die navorsingstudie die noodsaaklikheid vir voldoende beplanning en finansiering vir voldoende werksomstandighede gebaseer op die waarnemings van die bouperseelbestuur asook die boukonstruksiewerknemers.
\end{abstract}

Sleutelwoorde: Arbeidsproduktiwiteit, konstruksie, voldoende werk, volhoubare ontwikkeling, werksomstandighede, Zimbabwe 
Moyo, Crafford \& Emuze - Decent working conditions for improved...

\section{Introduction}

The workforce is the most important asset in the labour-intensive construction industry (Jang, Kim, Kim \& Kim, 2011: 93). Therefore, it is essential for contractors to improve the conditions in which people work in the industry. Construction labour productivity challenges are ever-present in the Zimbabwean construction industry, and the current national drive towards achieving decency of work presents the need for a convergent resolution. Although the national prerogative is "to promote and secure sustainable, full, productive and freely chosen decent employment for all the conditions of freedom, equity, security and human dignity" (Government of Zimbabwe, 2014: 25), lack of adequate health and safety requirements (Chigara \& Moyo, 2014b: 157), lack of on-site facilities and non-compliance with statutory regulatory authorities (Chigara \& Moyo, 2014a: 62) continue to affect construction workers. In addition, construction industry labour productivity continues to decline worldwide (Chartered Institute of Building, 2016:5; Jones, 2018: online), due to, among others, ineffective management practices, focus on inspection, unclear performance standards, labour shortages, technology impacts, and inadequate construction training (Forbes \& Ahmed, 2011: 28).

According to Mhlanga (2017: 3), productivity, profitability, performance and sustainability challenges within the Zimbabwean construction industry are inevitably affecting workers. Worker issues require a focus on human resources management. A focus on human resources is pertinent for achieving any meaningful advances. Lill (2008: 864) supports this by stating that "sustainable development of the construction industry has to concentrate not only on sustainable building technologies and construction materials but also on respectful and considerate labour management strategies". Lill's (2008: 864) stance is a further intimation that the workforce must be treated as the most valuable unreproducible resource. Similarly, Presley and Meade (2010: 440) refer to respect for employees as being essential to ensure sustainable construction. Comprehension of socially, economically and environmentally friendly embedded labour productivity has become relevant (Kocer, 2014: 354). Globalisation has necessitated the demand for economic, social and environmentally sustainable approaches for productivity improvement (Burgess \& Heap, 2012: 336). Therefore, fundamentals of the decent work agenda are embraced within the broader sustainability concept (International Labour Organization [ILO], 2009: 2, 3). This is owing to the ILO's (2013: 1) recognition of the 
fact that decent work is a means to achieve equitable, inclusive and sustainable development.

Several authors have investigated management-, manpower-, technical- and material-related factors, among others, that affect construction labour productivity (Horman \& Kenley, 2005: 52; Gong, Borcherding \& Caldas, 2011: 737; Chigara \& Moyo, 2014a: 57). However, few studies address the manner in which decent working conditions may enhance construction workers' productivity. Khan and Sandhu (2016: 491) assert that no extensive literature on decent work practices is available, owing to its recent advent as a discourse in 1999, as reported by the ILO (2006: 2). This hinders its consolidation into productivity resolutions. While the Zimbabwean construction industry faces significant productivity-related challenges, solutions should be sought within the increasing concept of sustainability (Presley \& Meade, 2010: 435), as it has mutated into a strategic authority for the future of construction (Galpin, Whittington \& Bell, 2015: 1). The objectives of the study are as follows: to determine the most significant decent working conditions that lead to improved construction workers' productivity on construction sites in Zimbabwe, and to determine significant statistical differences between the rankings of site managers/project managers and skilled and semiskilled artisans, due to age, gender, designation, educational level, and experience.

Consideration of the decency of the working conditions will culminate in improved construction skilled and semi-skilled workers' productivity and the generation of demographically targeted shortand long-term interventions. Durdyev and Ismail (2016:456) postulate the provision and control of decent working conditions as one of the most significant ways in which management can raise productivity. Salaj, Baricic and Maamari (2017: 510) reiterate that decent working conditions will ensure employee satisfaction. This will, consequently, improve productivity and introduce a better base value for both employees and employers. The dual benefit of raising construction workers' productivity and sustaining construction workers through ensuring decent work on construction sites is envisaged.

\section{Literature review}

In order to understand which of the most significant decent working conditions leads to productivity for construction workers on construction sites in Zimbabwe, it is important to introduce the present theory on decent work included in this article. The current 
theory focuses on the overall concepts of decent work and decent working conditions for construction workers on construction sites.

\subsection{Decent work}

The ILO (2006: 2) reports that the decent work concept was initiated with a primary goal to promote opportunities for both men and women to obtain productive work in conditions that encourage freedom, equality, security, and human rights. The report further states that, although considerable work has been undertaken along these lines, several questions remain unanswered. One of these critical questions is how the decent work approaches can be promoted in different countries with various economic, sociopolitical and environmental structures. Adhikari and Pandey (2011: 64) recommend that the government, workers and employers must play a significant role in order to achieve these objectives. To achieve this three-way solution, it is vital that all players' requirements be captured.

Demographic trends are fundamental to the decent work and sustainability discourse. Brennan and Cotgrave (2014: 317) support the consideration of various respondent groups in this sustainability endeavour, as it provides variability and the opportunity to explore diverse perspectives. The ILO (2018d: 25) states that trends differ among regions and countries, with age, gender and training aptitudes being decisive. The ILO (2018a: 72) supports disaggregation of labour statistics as crucial in order to identify critical issues and tendencies concerning specific demographic groups and to inform the devising of targeted policies. They further propose demographic variables of gender, age, education, occupation (designation), economic activity and status in employment as being the most widely used at the international level. The variables of age (generations), gender, designation, experience and educational levels form part of this study. The consideration of experience is crucial and emanates from the occupation variable as an extension that seeks to qualify the different effects or inputs, due to the years spent within the occupations.

Tolbize (2008: 2), Fernandes, Hyde, Ives, Fleischer, Evoy and Van Marrum (2012: online) as well as Schroer (2008: online) differentiate the characteristics of age generations concerning the world of work. Baby boomers are described as follows: protest against power characterising the formative years; individualistic; believe that hard work and sacrifice are the price to pay for success; more process than result oriented; confident; value health and wellness; seek job security, and thrive on the possibility for change. On the other hand, Generation X are described as follows: aspirers for work-life balance; independent, autonomous and self-reliant; not overly loyal 
to their employers; value continuous training and skills development; pragmatic and creative; not motivated by money, but demotivated by the lack thereof, and individualistic. They may like teamwork. Generation $Y$ are described as follows: most confident generation; value teamwork and collective action; multi-taskers; embrace diversity; adaptable to change; optimistic; seek flexibility and a balanced life; a less demanding, highly educated generation, and value training. Finally, Generation $Z$ are defined as follows: embrace diversity, adaptable to change, and the most technically savvy.

The significance of workforce-related factors such as overtime and associated fatigue, level of workforce training and workers' health and well-being (Durdyev \& Mbachu, 2017: 28) are paramount within the decent work agenda. Jimoh, Oyewobi, Adamu and Bajere (2016: 1429) also relate the need to address human resources challenges that negatively affect the participation of women in the Nigerian construction industry. The effect of demographics on the responses is pertinent, as highlighted in studies by Chileshe and Yirenkyi-Fianko (2012), Chigara and Moyo (2014a), as well as Adnan and Ressang (2016). Chileshe and Yirenkyi-Fianko (2012: 592) report on the impact of age on job satisfaction of white-collar construction workers. Chigara and Moyo (2014a: 57) also report on the significant difference in managers' and workers' responses regarding the factors affecting labour productivity within Zimbabwean building projects. Adnan and Ressang (2016: 197) include different designations and varying work experiences as variables for investigating the awareness of ergonomics on construction sites. Chileshe and Haupt (2010: 108) support this demographic analogy by highlighting the school of thought that claims the existence of differences concerning the impact of demographics, such as age and length of service, on the job satisfaction of construction workers in South Africa. This analysis helps the consideration of targeted intervention strategies within the relevant population ensure the realisation of decent work within the construction industry in its entirety.

\subsection{Decent working conditions}

The ILO (2018e: 15) states that construction sites in developing economies are characterised by the most precarious working conditions that include unsafe practices and unfair workloads for workers. Factors of poor workmanship, absenteeism and lateness, as well as accidents and occupational hazards must be eliminated in the work process (Chigara \& Moyo, 2014a: 62; Chigara \& Moyo, 2014b: 150) through the provision of adequate on-site conditions and the assurance of realistically set standard outputs. 
This translates to proper management and personnel policy for creating a satisfying work environment, developing appropriate training for skills, and creating better working conditions.

The Government of Zimbabwe (2013: 279) has considered important working conditions within its statutory framework. However, the translation of these conditions within the productivity measurement scope falls short (Moyo, Mangore \& Chigara, 2014: 43). The statutory instrument fails to contribute towards a standardised framework for undertaking productivity measurement construction company level through its failure to specify required decent working conditions (Moyo, Mangore \& Chigara, 2014: 43, 50). Furthermore, as these decent working conditions are established, sustainability dimensions will be incorporated into productivity measurement. The ILO (2018a: 15; 2018b: 3) also indicates several working conditions that need intensive attention within the decent work discourse. These include health and safety, working time, remuneration, and social protection. Hartrich (2018: 2) also highlights challenges of highrisk, physical demands, personal safety concerns and operating heat-intensive machinery for construction workers in Rwanda, Zambia and Mozambique. The ILO (2018b: 32) recommends that sustainability concerns and needs of workers include social dialogue, social protection, and occupational health and safety. Therefore, conditions of occupational health and safety organisation, ergonomics, personal protective equipment, climatic conditions, working time, work premises, and welfare facilities are considered within this objective, as they relate to the human aspect of work and are dignified and satisfactory to the worker (Chigara \& Moyo, 2014a; Chigara \& Moyo, 2014b; ILO, 2018a; Hartrich, 2018; ILO, 2018b).

\subsubsection{Occupational safety and health}

The ILO (2018e: 20) states that occupational safety and health $(\mathrm{OSH})$ is an inherent risk on construction sites in developing countries, where a preventative safety culture is extremely rare. Nunez and Villanueva $(2011$ : 56, 66) highlight the lack of consideration of OSH activities within the sources of the intellectual capital of a company. Due to this, they indicate the need for companies to invest in safety intellectual capital within their human capital. This has inevitably exacerbated the implementation burden of OSH on construction sites (Chigara \& Moyo, 2014b: 155). Although legislation and compliance have also been set to address OSH challenges on construction sites, the challenges persist (Sherratt \& Sherratt, 2017: 389). This is partly owing to contractors' resisting current OSH legislation (Wadick, 2010: 108) and to the fragmented nature of the industry 
(Emuze \& Smallwood, 2014: 294). However, the goal is to effectively plan and implement adequate OSH organisation on construction sites that not only reduces injuries on sites, but also enhances productivity and improves worker morale (Reese, 2016: 125).

HareandCameron(2012:193) reiteratethattheeffectivemanagement of firms must embrace OSH management as an integrated process. In support of this, De Silva and Wimalaratne (2012: 387) associate challenges in improving performance in the Sri Lankan construction industry regarding accountable parties disregarding OSH culture. $\mathrm{OSH}$ must be a shared duty among the stakeholders. Oswald, Sherratt and Smith (2017: 370) suggest the implementation of reward systems as a strategy to encourage safe behaviour on sites. This has cumulative benefits, as confirmed by Chaturvedi, Thakkar and Shankar (2018: 350) who reported that safety gains on construction sites improve workers' performance and advised on the introduction of a system that rewards positive safety performance.

\subsubsection{Ergonomics}

While ergonomics is synonymous with $\mathrm{OSH}$, the lack of awareness of ergonomics on construction sites, due to inadequate enforcement (Adnan \& Ressang, 2016: 190), contributes to it being considered separately. Furthermore, traditional health promotion, which is synonymous with ergonomics and maximises health, well-being and productivity in the workplace, has been addressed separately from OSH (Obiozo \& Smallwood, 2014: 139).

Adnan and Ressang (2016: 190) reveal that the challenge of implementing ergonomics on construction sites is due to their dynamism and hazardous nature. Eaves, Gyi and Gibb (2013: 101) also acknowledge that ergonomics and workplace design can have a substantial effect on working practices. Goldswain and Smallwood (2013: 359) also mention health, safety and ergonomics as being caused by inadequacies in designs. In addition, Coupaud (2017: 93) deplores the emergence of musculoskeletal and psychosomatic disorders in industrialised countries as new risks for workers. However, Obiozo and Smallwood (2014: 146) support the greening of construction sites as a strategy to enhance ergonomics and performance on those same sites. Chinyere (2014: 78) also supports the adoption of optimal work postures for greater job satisfaction. As such, proactive ergonomics is best emphasised during the generation of productivity outputs and method study, as this then sets a standard working procedure for the specific activities. 
Moyo, Crafford \& Emuze - Decent working conditions for improved...

\subsubsection{Personal protective equipment}

The Government of Zimbabwe (2013: 280) details the personal protective equipment (PPE) that employers must provide. The ILO (2018e: 20) laments the provision of PPE as merely a boxticking exercise that is not effective in protecting workers against construction-site accidents. Lack of adequate protection for workers is one of the significant conditions that have led to fatalities and near fatalities in the South African construction industry (Emuze, 2017: 330). Akawi, Musonda and Pretorius (2017: 478) attribute these challenges to pricing shortcomings emanating from competition and the lack of detail in consideration of health and safety aspects such as personal protective equipment.

Taderera (2012: 99) outlines the importance of competent hazard prevention through prevention and control measures assessment, the goal of which is to specify adequate and relevant PPE. Implementation of a job hazard analysis will also aid in determining task-appropriate personal protective equipment (Occupational Safety and Health Administration, 2002: 1). Consideration of "co-workers' actual safety response" could also be effective in ensuring that all workers are appropriately protected (Lingard, Cooke \& Blismas, 2011: 159). It is, however, difficult to achieve this in Zimbabwe, due to the fragmented approach deployed by construction project stakeholders concerning OSH issues (Chigara \& Moyo, 2014b: 150). Thus, all variables must be considered before appropriate personal protective equipment can be selected and this must be operationalised during productivity measurement.

\subsubsection{Climatic conditions}

Hasan, Baroudi, Elmualim and Rameezdeen (2018: 932) reiterate that climatic conditions are one of the most significant factors that affect labour productivity. In support of this, Durdyev and Ismail (2016: 456) posit poor climatic conditions as one of the riskiest productivity external constraints. While the compound effects of exposure to these extreme climatic conditions are low task productivity (Mincks \& Johnston, 2004: 193), it is apparent that the extent can only be determined within specific environments. In terms of the global threat of the climate change challenge, Zimbabwe has not been spared. While empirical studies by Chigara and Smallwood (2016: 290) have shown a perceived positive effect of ambient temperatures on workers' productivity, there is a need to ascertain the extent to which this has affected construction labour productivity. Langston, Song and Purdey (2008: 65), who revealed significant satisfaction 
differences by employees on commercial buildings in aspects of air quality and temperature, evidence this.

Mincks and Johnston (2004: 193) further advocate for preconstruction planning that thoroughly analyses the relationship between productivity loss and the cost of temporary weather protection for cost-effective decisions to be made. Beyond the cost aspect, Sarode and Shirasath (2012: 2736) state that a comfortable work environment is one where workers are exposed to a proper range of temperature, adequate ventilation and adequate humidity for work in confined spaces. They further report that the provision of these would guarantee improved employee productivity. Chan, Yam, Chung and Yi (2012: 60) recognise that construction workers are increasingly being subjected to heat stress from both confined spaces and outdoor physical work areas. The ILO (2018c: 26) also acknowledges that the rising global temperatures have led to the prevalence of heat stress. This has reduced worker performance and given rise to negative occupational health effects and workplace injuries. While recognising the difficulty in controlling climatic conditions, it is undeniable that failure to appropriately plan for these can have disastrous consequences.

\subsubsection{Working time}

Smith and Zagelmeyer (2010: 393) define working time as the hours worked by employees within organisations. They further highlight that the use of "overtime" does not have the same positive outcome as normal working time and that non-standard working time arrangements create constraints on the work-life balance of employees. Arditi, Ayrancioglu and Shi (2005: 488) also discourage the adoption of night-time construction because of its being more hazardous owing to lighting and human factors. Emuze (2017: 330) recognises that long working hours contribute to workers' unsafe acts. Construction companies need to move away from a culture of working long hours, in order to improve the work-life balance of employees. Townsend, Lingard, Bradley and Brown (2011: 70) suggest that this is a positive way for organisations to reach productivity targets.

To utilise working time efficiently, Kattenbach, Demerouti and Nachreiner (2010: 279) report that flexible working time has become an accepted model in most of the business areas. The Government of Zimbabwe (2013: 278) encourages the adoption of a 44-hour standard working week, and the National Employment Council of the construction industry in Zimbabwe has generated productivity outputs based on these standard working times. It is imperative that 
Moyo, Crafford \& Emuze - Decent working conditions for improved...

construction companies, which generate their productivity outputs, recognise the regulated standard working time and factor in any extra hours in their computations of productivity outputs.

\subsubsection{Workplace conditions}

Beyond the need for adequate regulation, construction companies have the responsibility to maintain their premises because of the benefits, including timeous completion, that can accrue to them (AboagyeNimo \& Emuze, 2017: 285). Obiozo and Smallwood (2015: online) suggest "greening" worksite premises, in order to increase workers' productivity. Sarode and Shirasath (2012: 2735) confirm the direct impact of the physical aspects of the work environment on the productivity, health and safety as well as morale of workers. Abrey and Smallwood (2014: 7) empirically determined that unsatisfactory working conditions harmfully affect productivity on construction sites. Similarly, Mincks and Johnston (2004: 191) state that the organisation of work premises will affect workers' productivity. They further mention that adequate planning and crew supervision are fundamental to significantly reduce the impact of inadequate conditions.

March (2009:9) reports that the provision of adequate services of water and sanitation is essential to ensure that workers are not distracted from their core tasks. Naoum (2016: 413) contends that the work environment and constraints on workers' performance are factors that are highly likely to affect on-site labour productivity on construction sites. It is evident that adequate work premises are essential for improving construction labour productivity on construction sites. It is, therefore, incumbent on construction companies to address this condition effectively. Sarode and Shirasath (2012: 2737) emphasise that nurturing workers is achievable through providing suitable work premises.

\subsubsection{Welfare facilities}

The minimal requirements concerning welfare facilities are expounded in the Factories and Works Act (22 of 2001), Labour Act (13 of 2002), and Public Health Act, Chapter 15:09. However, lack of appropriate regulation translates to construction companies' inadequately budgeting for these and subverting minimum requirements during the construction phase (Akawi, Musonda \& Pretorius, 2017: 520). The Government of Zimbabwe (2013: 281) is silent on the standards of facilities that should be provided. Hence, construction companies are not compelled by any specific regulation. However, various authors acknowledge the importance of welfare facilities within the productivity enhancement drive (Mincks 
\& Johnson, 2004; March, 2009; Salaj et al., 2017). The Construction Industry Development Board (CIDB) (2015: 14) indicates that the provision of adequate welfare facilities has a significant impact on construction workers' productivity. Mincks and Johnston (2004: 213) also report that the provision of adequate temporary facilities related to project requirements has a distinct impact on the profitability of the construction project and craftsperson productivity. Obiozo and Smallwood (2015: online) also recommend the creation of a construction site that is beneficial and comfortable for productivity improvement. Related to this, Smallwood and Haupt (2009: 1263) recommend welfare facilities that are gender sensitive on construction sites, as these affect wellness and performance.

March (2009: 10) supports the provision of welfare facilities such as the provision of sanitary conveniences, safe drinking water and rest, washing, changing and eating facilities on construction sites. The provision of such facilities leads to the minimization of productivity losses, due to employees' satisfaction (Salaj et al., 2017: 520). Welfare facilities are paramount to the health and well-being of workers and are regulated through various Acts and statutory instruments. This fragmented approach potentially affects their effective regulation.

\section{Methodology}

\subsection{Research design}

Thisresearch determined themostsignificantdecentworking conditions that lead to improved construction workers' (skilled and semi-skilled) productivity and statistically determine significant differences in the ranking of these conditions, due to the demographics of respondents. A mono-method quantitative research study was used to do a crosssectional questionnaire survey on decent working conditions that significantly improve productivity as tested by respondents' ratings. Naoum (2013:39) describes quantitative research as an inquiry based on testing a hypothesis of theory composed of variables concerning social or human problems, usually by gathering numeric data in a systematic format. It also allows for descriptive and inferential statistical analysis (Naoum, 2013: 104). In this study, the SPSS chi-square test for significance results, together with questionnaire survey results on the ranking of decent working conditions, set the decent working conditions that are significant to improve construction workers' productivity. These results form the dependent variables that were tested against demographic (independent) variables to establish whether there are statistically significant differences in the ranking of 
Moyo, Crafford \& Emuze - Decent working conditions for improved...

decent working conditions among respondent categories (Blumberg, Cooper \& Schindler, 2008: 670).

\subsection{Population, sampling and response rate}

The population for the study consisted of managers from all the construction companies registered with the Construction Industry Federation of Zimbabwe (CIFOZ) and based in Harare and Bulawayo as well as of construction workers on 13 construction sites, six residential and seven commercial, situated within the same study area. These projects were undertaken by category $A$ and $B$ contractors that reflect the most organisationally and technically competent and financially stable companies in Zimbabwe. Random sampling was utilised to select 83 construction companies, and, from these, 68 site or project managers were targeted to participate (Alvi, 2016: 35). Through the National Social Security Authority database, 142 construction site workers from the different classes ( 1 to 4 ) were purposively soughed and invited to participate. These classes include skilled tradespeople such as bricklayers (20), carpenters (15), and painters (14), as well as semi-skilled exempted bricklayers (24), carpenters (15), and painters (15) who were selected based on the premise that these are trades related to the critical path of construction projects and that they are benchmarked by the National Employment Council of the construction industry. The survey was undertaken with a sample of 172. The sample size for research done in constructionrelated populations was calculated in accordance with the table recommended by Krejcie \& Morgan (1970: 608). From the table, the recommended sample size for a population of 220 is 140 , and for 250 , 150. This recommendation validates the sample size of 172 as efficient for the population of 225 in Table 1.

Table 1: Response rate

\begin{tabular}{|c|c|c|c|c|c|}
\hline $\begin{array}{l}\text { Respondent } \\
\text { category }\end{array}$ & $\begin{array}{l}\text { Respondent } \\
\text { group }\end{array}$ & Population & $\begin{array}{l}\text { Sample } \\
\text { size }\end{array}$ & Responses & $\begin{array}{c}\text { Response } \\
\text { rate (\%) }\end{array}$ \\
\hline Managers & $\begin{array}{l}\text { Site or project } \\
\text { managers }\end{array}$ & 83 & 68 & 54 & 80.3 \\
\hline \multirow{4}{*}{$\begin{array}{l}\text { Skilled workers } \\
\text { (classes } 1 \text { to 4) }\end{array}$} & Bricklayers & 28 & 20 & 16 & 80.0 \\
\hline & Carpenter/joiner & 19 & 15 & 11 & 73.3 \\
\hline & Painter & 18 & 14 & 10 & 71.4 \\
\hline & Total & 65 & 49 & 37 & 74.9 \\
\hline \multirow{4}{*}{$\begin{array}{l}\text { Semi-skilled } \\
\text { workers } \\
\text { (worker } \\
\text { exempted) }\end{array}$} & Bricklayer & 35 & 24 & 20 & 83.3 \\
\hline & Carpenter/joiner & 21 & 15 & 12 & 80.0 \\
\hline & Painter & 21 & 15 & 12 & 80.0 \\
\hline & Total & 77 & 55 & 44 & 81.1 \\
\hline Total & & 225 & 172 & 135 & 78.5 \\
\hline
\end{tabular}


The survey achieved an overall response rate of $78.5 \%$, with $80.3 \%$ for site/project managers, $74.9 \%$ for skilled, and $81.1 \%$ for semi-skilled workers. Johnson and Owens (2003: 132) state that, although no formal policies exist regarding minimally acceptable response rates, it is generally indicated that studies with response rates of less than $60 \%$ are rarely accepted for publication in journals. Thus, an overall response rate of $78.5 \%$ is acceptable and supports the generalisation of results.

\subsection{Questionnaire design and administration}

Self-administered and e-mailed questionnaires were used to collect data from site managers and project managers in construction companies and on construction sites in Harare, Bulawayo, and Shurugwi from 3 September 2018 to 14 December 2018. Intervieweradministered questionnaires were also conducted by the first author on skilled and semi-skilled workers within the study area. These were done in English, Shona and Ndebele to enable respondents to accurately understand the questions and competently express themselves. Both types of questionnaires consisted of two sections. The first section, on the respondent's demographic profile, obtained personal information on age, gender, designation, educational level, and experience. The second section set 7 Likert-scale items on the construct decent working conditions. Respondents were requested to rate how significantly these items improve construction labour productivity on sites. The data from these measurements forms the Likert-scale items used in the descriptive analysis of this study. To reduce the respondents' bias, closed-ended questions were preferred for section two (Akintoye \& Main, 2007: 601).

The questionnaire was administered to the study sample, along with a covering letter stating the purpose of the research, and the guarantee that the information given by the respondents would be treated as confidential and that no names would be mentioned in the research (Gray, 2009: 69). Interview questionnaires were completed anonymously to ensure a true reflection of the respondents' views and to meet the ethical criterion of confidentiality (Gray 2009: 73).

\subsection{Data analysis}

The Statistical Package for Social Science (SPSS) version 24 was used to determine the significant working conditions and their analysability against demographic variables, by using inferential statistics (Pallant, 2013). The frequencies and percentages of responses were generated and reported, in order to analyse the respondents' profile. 
To do the normality test for decent working conditions, Ghasemi and Zahediasl (2012: 486) indicate that the Kolmogorov-Smirnov test and the Shapiro-Wilk test are used to test normality. These compare the scores in the sample to a normally distributed set of scores with the same mean and standard deviation, where a non-significant result (sig value >0.05) indicates normality. The test for normality culminated in the decision to use parametric or non-parametric tests for significance testing and significant differences owing to demographics. As the result (Table 4) was <0.05, non-parametric tests that include the Pearson chi-square test, the Mann-Whitney $U$ test and the Kruskal-Wallis test were used.

For the analysis and the ranking of decent working conditions, a 5-point Likert scale was used to measure how strongly respondents felt regarding the statements in the Likert-scale construct. Likert-scale rankings are effective where numbers can be used to quantify the results of measuring behaviours, attitudes, preferences, and even perceptions (Wegner, 2012: 11; Naoum, 2013: 89). For the purposes of analysis, it is important to note that the following scale measurement was used regarding mean scores (MSs), where 1 = not significant; 2 = of little significance; 3 = somewhat significant; 4 = significant, and 5 = very significant. Data was analysed using frequencies and MS rankings.

For the analysis of the significance of decent working conditions, since it was erroneously perceived that Likert scales intervals are equidistant (Yelland, 2010: 2), correspondence analysis was used to re-scale the 5-point Likert scale from ordinal to interval data (Nkado \& Meyer, 2001: 485; Yelland, 2010: 2). The means of the re-scaled respondents' ratings were then considered, and the most significant were selected and used for the Pearson chi-square test. Table 2 shows the re-scaling.

Table 2: Re-scaling of the 5-point Likert scale for rating significance of decent working conditions

\begin{tabular}{|l|l|c|c|c|c|}
\hline \multicolumn{2}{|c|}{$\begin{array}{c}\text { Likert scale for } \\
\text { significance }\end{array}$} & $\begin{array}{c}\text { Axis 1 } \\
\text { co-ordinate }\end{array}$ & $\begin{array}{c}\text { Axis 2 } \\
\text { co-ordinate }\end{array}$ & $\begin{array}{c}\text { Euclidean } \\
\text { distance }\end{array}$ & $\begin{array}{c}\text { Adjusted } \\
\text { 5-point scale }\end{array}$ \\
\hline 1 & Not significant & 0 & 0 & & 1 \\
\hline 2 & Of little significance & -0.119 & -0.036 & 0.124 & 1.116 \\
\hline 3 & $\begin{array}{l}\text { Somewhat } \\
\text { significant }\end{array}$ & -0.174 & 0.405 & 0.444 & 1.529 \\
\hline 4 & Significant & -1.141 & -0.231 & 1.157 & 2.604 \\
\hline 5 & Very significant & 1.435 & -0.138 & 2.578 & 5 \\
\hline
\end{tabular}


The Pearson chi-square goodness-of-fit test was used to test whether decent working conditions, identified from the ranking results (data in the model), were good enough for inferential testing. This test (Table 4) compares the observed and expected frequencies of events and non-events, in order to assess how well the model fits the data (Kothari, 2009: 236). For this study, the significance level was set at $p<0.05$. This means that, if the $p$-value for the goodness-offit test is lower than 0.05, the significant decent working conditions are established and can be used for inferential analysis. In addition, Cramer's statistic was used to measure the size of the association between decent working conditions and improved productivity. The highest Cramer value, between 0 and 1, was deemed to have the highest significance (Field, 2014: 743).

For the inferential analysis, the Kruskal Wallis and Mann-Whitney $U$ tests were used to test the statistical differences in rankings between site and project managers and skilled construction workers. Kothari (2009: 298) describes the Kruskal-Wallis one-way analysis of variance as a rank-based non-parametric test that is used to determine if there are statistically significant differences between two or more groups of an independent variable on a continuous or ordinal dependent variable. Blumberg, Cooper and Schindler (2008: 670) define a Mann-Whitney $U$ test as a non-parametric test for comparing the central tendency of two independent samples. To find a relationship between the dependent (ranking of decent working conditions) and independent (demographics) variables, the statistical significance level is set at $p=0.05$ and the effect size scale to measure the strength of the relationship as $r=0.10$ (small effect); $r=0.30$ (medium effect); $r=0.50$ (large effect) (Field, 2014: 79, 313).

A Cronbach alpha reliability test was undertaken to analyse the internal consistency of reliability of the statements on decent working conditions (Taherdoost, 2016: 33). George and Mallery (2003: 53) provide the following rules of thumb: $>0.90$ - Excellent; $>0.80$ - Good; $>0.70$ - Acceptable; $>0.60$ - Questionable; $>0.50$ - Poor, and $<0.50-$ Unacceptable for interpreting Cronbach's alpha coefficients. In the current study, a cut-off value of 0.80 was preferred.

\section{Findings and discussion}

\subsection{Demographics of respondents}

Table 3 presents the profile of respondents to the interview and questionnaire surveys. The distribution shows that Generation X (40\%) and Generation $Y(57.8 \%)$ were the best represented age groups, translating to ages between 24 and 51 years. 
Moyo, Crafford \& Emuze - Decent working conditions for improved...

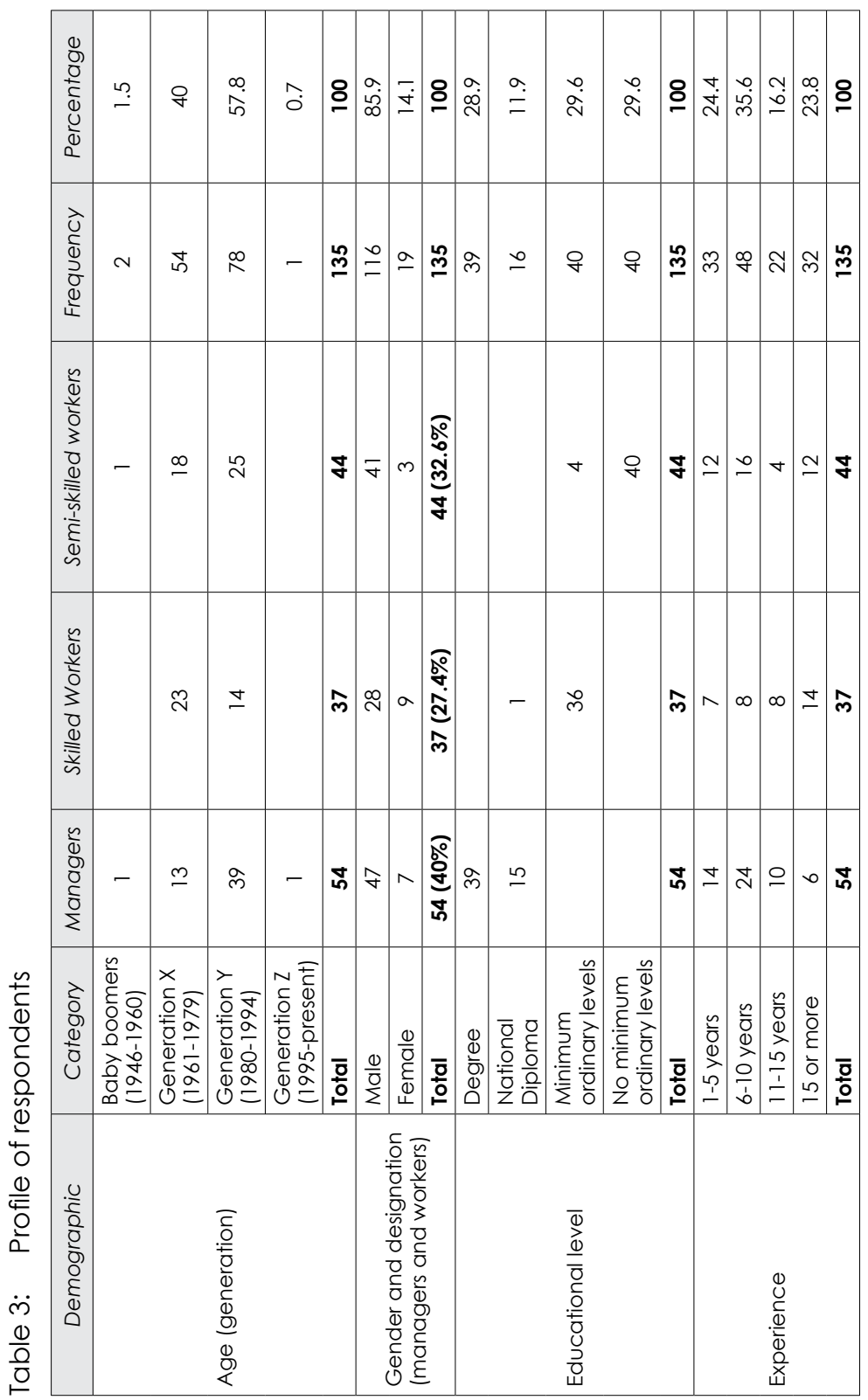


The advent of Generation $Y$ as the best represented age group has the potential to contribute positively to the study and sustainable development agenda. Tolbize (2008: 2) reports that they are adaptable to change and seek flexibility and a balanced life. The Generation X age group also has similar characteristics such as continuous training and skills development as those required for driving sustainable development. In addition, they are pragmatic, creative, and may like teamwork (Fernandes et al., 2012: online). These characteristics enable the effective implementation of decent work interventions related to the age of respondents.

Table 3 also shows that $85.9 \%$ of all the respondents are males and $14.1 \%$ are females. Although this may represent a skew in favour of males, it is a reflection of the representation in the construction industry, which is biased towards males. The results show that the requirement of the Zimbabwean Government for a gender-inclusive construction industry is still to be met (Government of Zimbabwe, 2014: 25). Skilled and semi-skilled workers $(60 \%)$ were the best represented designation, with site/project managers at $40 \%$. All relevant designations were also sufficiently represented in the study. The variability in the designation is bound to expose the inherent deficiencies in white- and blue-collar workers and assists in the development of targeted intervention strategies for the different designation of workers.

Most of the educational levels are well represented in the study, except those with no minimum ordinary levels that are poorly represented. The ILO (2018e: 22) reports that skill is a substantial contributor to decent work concerns in the construction sector. Therefore, the different education levels are expected to represent the varied decent work aptitudes. The majority of the respondents (35.6\%) have between 6-10 years' work experience, while the least represented range of work experience is between 11-15 years, reflecting $16.3 \%$ of the respondents. Generally, work experience results include all the ranges sufficiently. This is relevant towards ascertaining inclusivity of this study.

\subsection{Ranking and significance of decent working conditions}

Table 4 ranks the Cramer's value to show which of the seven decent working conditions is most significant towards improving construction skilled and semi-skilled workers' productivity on construction sites.

The average MS ranking of 4.50 is above the re-scaled rate of 2.604 in Table 2 and shows that respondents perceive all the decent working conditions significant towards improving construction skilled and semi-skilled workers' productivity on construction sites. 
Moyo, Crafford \& Emuze - Decent working conditions for improved...

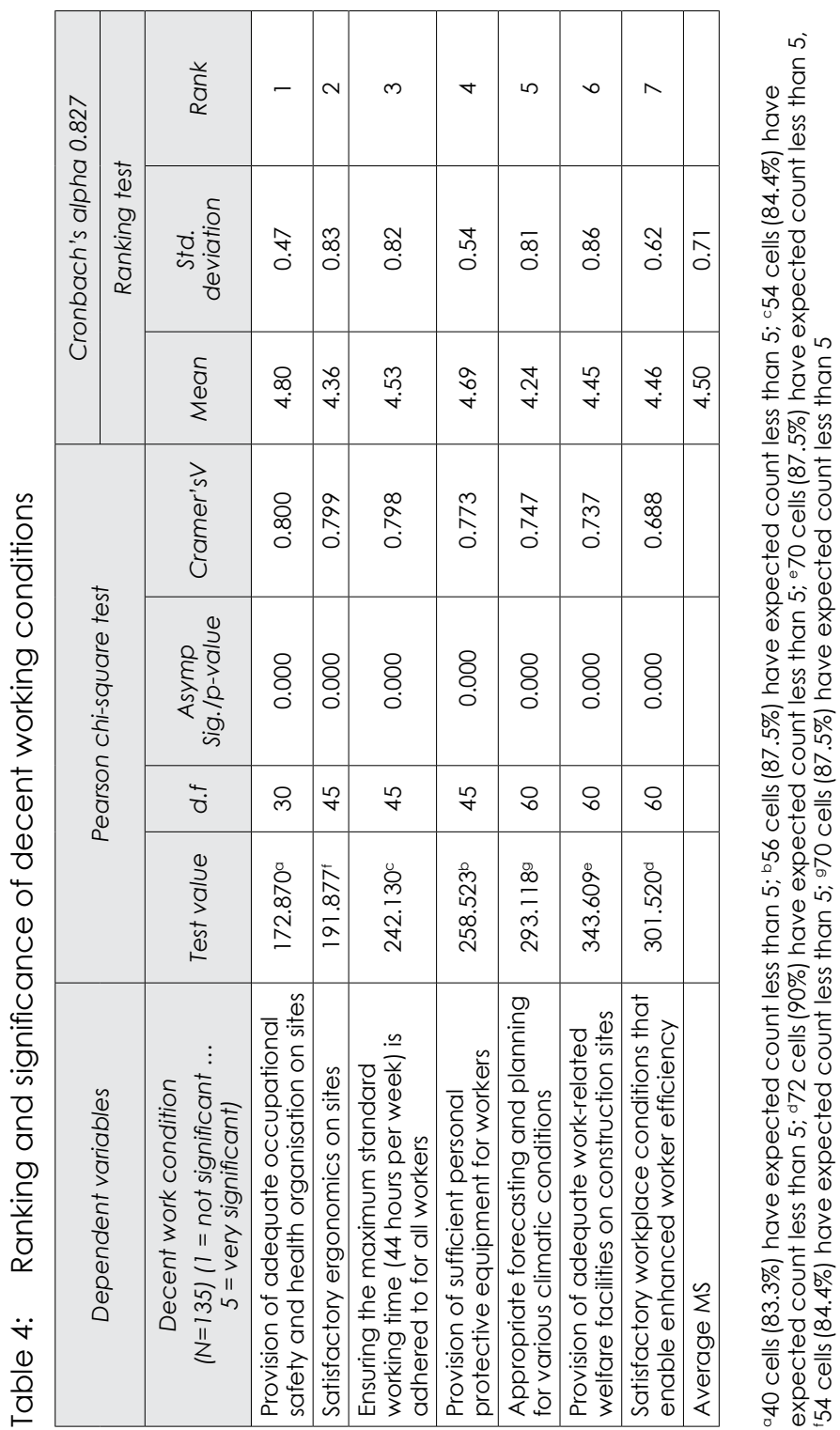


The Cronbach's alpha value of 0.827 is above the recommended value of 0.800, as considered by George and Mallery (2003: 53), showing that the seven decent working conditions are reliable and valid for improving construction skilled and semi-skilled workers' productivity. The Pearson chi-square goodness-of-fit test $(p<0.05)$ indicates that all decent working conditions statistically tested highly significant for improving construction productivity of skilled and semi-skilled workers. With highest Cramer value of 0.800 , "Provision of adequate occupational safety and health organisation on sites" is the decent working condition with the most influence to improve productive work for construction skilled and semi-skilled workers in Zimbabwe. This is supported by Moyo, Mangore and Chigara (2014: 43) who state that these conditions should be well articulated within the statutory frameworks and regulated within the construction industry. Durdyev and Ismail (2016: 456) as well as Salaj, Baricic and Maamari (2017: 510) emphasise the importance of the provision and control of decent working conditions as a significant way in which management can raise productivity.

\subsubsection{Discussion on ranking of significant decent working conditions}

The dual benefit of preserving human life and achieving high productivity is inevitable if construction companies in Zimbabwe inculcate this fundamental approach in their corporate strategies. Improving construction workers' productivity is borne out of ensuring that $\mathrm{OSH}$ conditions are accorded the importance they deserve. Indeed, workers' health and well-being is a significant factor that affects labour productivity (Durdyev \& Mbachu, 2017: 28). The lack of provision of these conditions by the construction companies will have disastrous consequences on productivity levels (Chigara \& Moyo, 2014a: 62). De Silva and Wimalaratne (2012: 387) justify improving performance in the construction industry by adopting an $\mathrm{OHS}$ culture. This can be enhanced through initially integrating $\mathrm{OSH}$ legislation within a construction industry bill (Sherratt \& Sherratt, 2017: 389, Chigara \& Moyo, 2014b: 150). Recommendations by Oswald et al. (2017: 370) to offer reward systems aligned to OSH can also be implemented. Thus, the resolution of OSH inadequacies guarantees productivity gains.

Related to this, the provision of adequate personal protective equipment mentioned by the respondents is just as essential. Providing adequate personal protective equipment and ensuring the adherence to a maximum standard working time of 44 hours per week were ranked second and third with mean scores of 4.69 
and 4.53, respectively. Provision of adequate personal protective equipment should be preceded by appropriate task analysis (Occupational Safety and Health Administration, 2002: 1; Lingard ef al., 2011: 159; Taderera, 2012: 99). Furthermore, sufficient OSH pricing will go a long way in ensuring its sufficiency in terms of provision of adequate personal protective equipment (Akawi, Musonda \& Pretorius, 2017: 478). Respondents agree that adherence to a 44-hour working week is paramount to enhancing labour productivity.

Regarding construction firms embracing "overtime" as a remedy to delays, Smith and Zagelmeyer (2010:394) as well as Emuze (2017:330) dispute this notion, asserting that it provides a net loss as diminished productivity is realised. Townsend et al. (2011: 77) motivate for the observance to a standard working time by advocating for an appropriate work-life balance for workers, which has a positive psychological effect on their performance. Appropriate forecasting and planning for various climatic conditions had the lowest ranking, although the score was high, potentially due to the not yet so adverse climatic conditions within the country. However, Chan et al. (2012: 60) and Chigara and Smallwood (2016: 290) recognise the effects of climate change in developing countries, and the significant rating of 4.24 supports this. Initiatives by the ILO (2006: 2) and Adhikari and Pandey (201 1: 64) on the importance of decent working conditions are evident through the respondents' perceptions. It is sensible that, as the construction industry evolves, the integration of working conditions for decent work is ascertained.

\subsection{Inferential analysis results}

\subsubsection{Kruskal-Wallis test on demographic profile vs decent working conditions}

The Kruskal-Wallis test was used to determine any differences in ranking of decent working conditions between the respondent groups based on their demographic profile. Table 5 shows that there was no statistically significant difference in the collective decent working conditions concerning age (0.086), gender (0.352) and experience of respondents (0.553). However, designation (0.000) and educational levels of respondents $(0.001)$ showed a statistically significant difference, since their $p$-value was $<0.05$.

The demographic "educational level" had a statistically significant difference in the following decent working conditions, namely "provision of sufficient personal protective equipment for workers"; "provision of adequate work-related welfare facilities on construction 


\begin{tabular}{|c|c|c|c|c|c|c|c|c|}
\hline 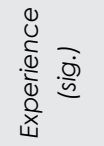 & 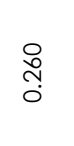 & $\begin{array}{l}\text { ్. } \\
\text { ○े }\end{array}$ & $\begin{array}{c}\text { 尺 } \\
\infty \\
0 \\
0\end{array}$ & $\begin{array}{l}8 \\
\text { ஸ̣ } \\
0\end{array}$ & $\begin{array}{l}\stackrel{0}{ } \\
\infty \\
0 \\
0\end{array}$ & ஓ & $\underset{\substack{0 \\
0}}{0}$ & $\begin{array}{l}\stackrel{M}{\Lambda} \\
\stackrel{n}{0} \\
0\end{array}$ \\
\hline 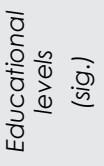 & $\frac{8}{\frac{8}{\circ}}$ & \& & $\frac{}{\stackrel{\circ}{\circ}}$ & $\begin{array}{l}\text { ㅇ } \\
\text { ọ } \\
\text { ○े }\end{array}$ & $\begin{array}{l}8 \\
8 \\
0\end{array}$ & $\begin{array}{l}\text { 융 } \\
\text { ○. }\end{array}$ & 웅 & $\overline{8}$ \\
\hline 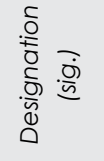 & $\frac{8}{\circ}$ & : & $\begin{array}{l}\circ \\
\circ \\
\circ\end{array}$ & ণ্ণি & $\begin{array}{l}\text { ઠ } \\
\text { ○் }\end{array}$ & 응 & 웅 & $\begin{array}{l}8 \\
8 \\
0\end{array}$ \\
\hline 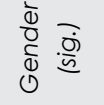 & $\begin{array}{l}\text { ㅇ. } \\
\infty \\
\infty \\
0\end{array}$ & 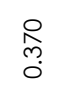 & $\frac{\stackrel{\rho}{\circ}}{\circ}$ & $\frac{O}{\stackrel{0}{0}}$ & $\begin{array}{l}8 \\
\text { ণे } \\
\circ\end{array}$ & $\begin{array}{l}8 \\
\infty \\
0 \\
0 \\
0\end{array}$ & $\begin{array}{l}\circ \\
\infty \\
0 \\
0\end{array}$ & $\begin{array}{l}\text { N } \\
\text { } \\
0 \\
0\end{array}$ \\
\hline ه) & $\begin{array}{l}0 \\
0 \\
\infty \\
0\end{array}$ & $\stackrel{\text { P }}{\stackrel{0}{0}}$ & $\begin{array}{l}0 \\
\stackrel{n}{\circ} \\
0\end{array}$ & $\frac{\stackrel{m}{0}}{0}$ & $\frac{\infty}{\infty}$ & $\frac{}{\frac{1}{0}}$ & $\begin{array}{l}0 \\
0 \\
0 \\
0\end{array}$ & $\begin{array}{l}\circ \\
0 \\
0 \\
0\end{array}$ \\
\hline 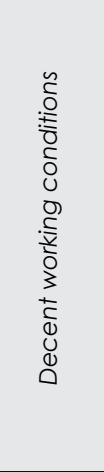 & 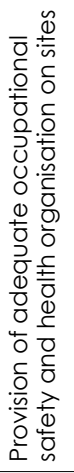 & 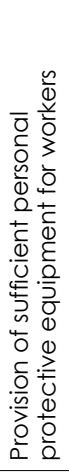 & 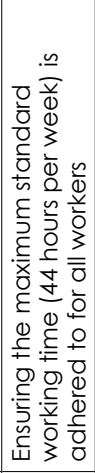 & 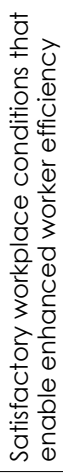 & 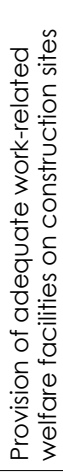 & 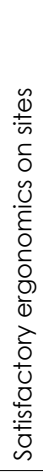 & 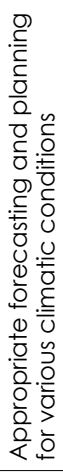 & \\
\hline 美 & - & $\sim$ & $m$ & $\nabla$ & in & 0 & $\Lambda$ & 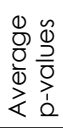 \\
\hline
\end{tabular}


Moyo, Crafford \& Emuze - Decent working conditions for improved...

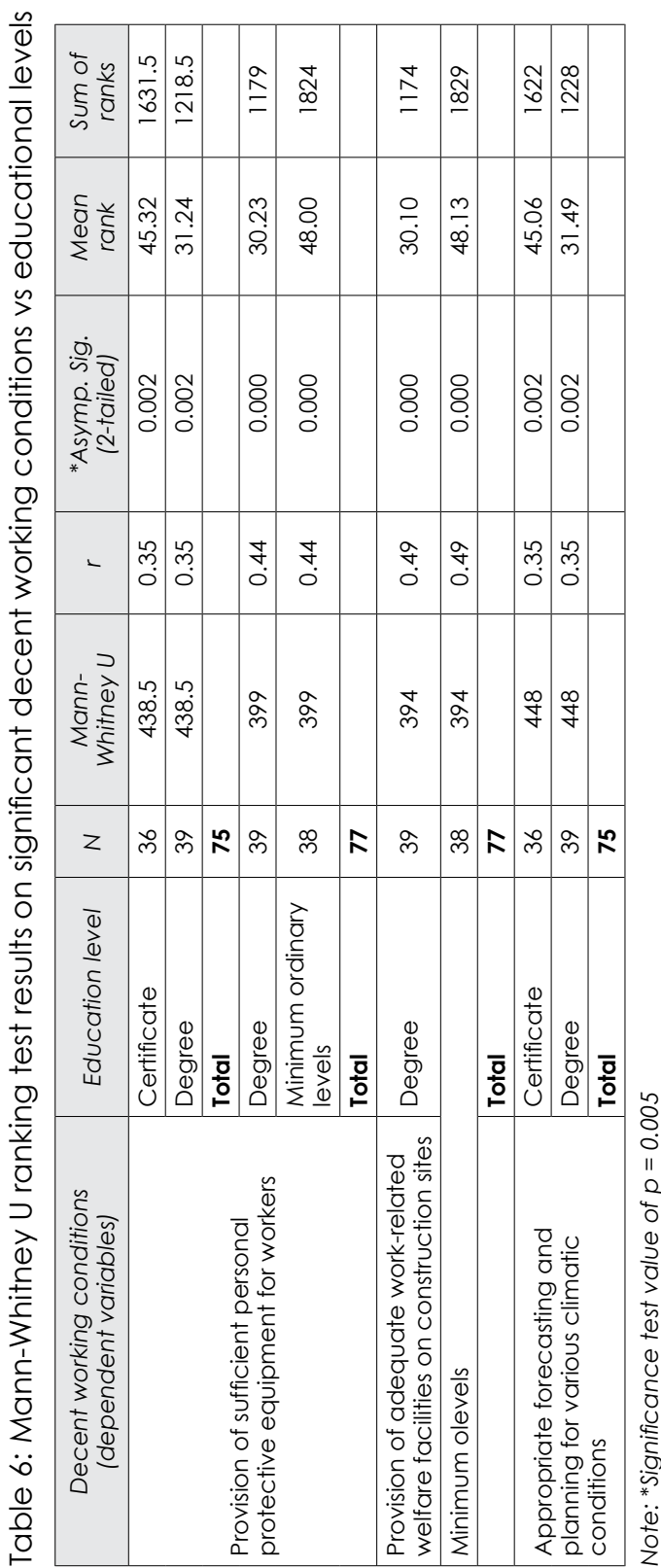


sites", and "appropriate forecasting and planning for various climatic conditions". However, since the Kruskal-Wallis test shows the statistically significant difference in the combined perceptions on the significance of decent working conditions that ensure improved construction labour productivity, it did not establish where the significant differences lie across the five different education levels. In such instances, Osei-kyesi and Chan (2017: 32) support a post-hoc analysis using the Mann-Whitney $U$ test.

\subsubsection{Mann-Whitney U test on educational levels vs selected decent working conditions}

The Mann-Whitney $U$ test on the significant strategies using a recalculated alpha value (p) of 0.005 (0.05/10). Dividing by 10 relates to the number of groups that emanate from the five different educational levels. Therefore, from Table 5, the following decent working conditions were considered for ranking and significance testing, namely "provision of sufficient personal protective equipment for workers"; "provision of adequate work-related welfare facilities on construction sites", and "appropriate forecasting and planning for various climatic conditions".

Table 6 shows that there was a statistically significant difference in "provision of sufficient personal protective equipment for workers" mean rank score between certificate (45.32) and degree (31.24) holders and also between degree (30.23) and those with the minimum ordinary level (48.00) subjects required to have passed, since the $p$ values of 0.002 and 0.000 are $<0.005$, with both having a medium effect size ( $r$ ) of 0.35 and 0.44 , respectively.

Field (2014: 225) states that the Mann-Whitney $U$ test interpretation relies on scores being ranked from lowest to highest; thus, the lowest mean rank is the group with the greatest number of lower scores. This shows that certificate holders, who are predominantly skilled workers, view this condition as being more significant than the degree holders, who are predominantly site or project managers. The certificate holders view this condition as critical for enhancing construction labour productivity as compared to the degree holders. The differences due to the level of workforce training are evident as supported by Durdyev and Mbachu (2017: 28). Despite the lack of appropriate instruction for those with the minimum ordinary levels, they perceive that the provision of sufficient personal protective equipment for workers is fundamental to enhancing construction 
labour productivity. Generally, the skilled and semi-skilled workers with certificates and minimum ordinary levels have a higher regard for this working condition compared to the degree holders.

For the "provision of adequate work-related welfare facilities on construction sites", the results show that there is a significant difference in mean rank score between degree holders (30.10) and those with the minimum ordinary levels (48.13), since the p-value of 0.000 is $<0.005$ with a medium effect size of 0.49 . This shows that those with minimum ordinary levels, who are predominantly semi-skilled workers, view this condition as being more significant, since they are more affected than the degree holders, who are predominantly site or project managers.

For "appropriate forecasting and planning for various climatic conditions", the results show that there is a significant difference in mean rank score between certificate holders (45.06) and degree holders (31.49), since the p-value of 0.002 is $<0.005$ with a medium effect size of 0.35 . This shows that those with certificates, who are predominantly semi-skilled workers, view this condition as being more significant, since they are more affected than the degree holders, who are predominantly site or project managers. Chigara and Moyo (2014a: 57) as well as Durdyev and Mbachu (2017: 385) confirm the apparent differences, due to educational levels.

\subsection{Compared ranking results of decent working conditions among designation groups}

In Table 5, the Kruskal-Wallis test shows that the demographic "designation" had statistically significant differences in the following decent working conditions, namely "provision of sufficient personal protective equipment for workers"; "provision of adequate work-related welfare facilities on construction sites", and "appropriate forecasting and planning for various climatic conditions", since their $p$-value was $<0.005$. Table 7 shows a comparison of site or project managers' (SPM) and skilled and semi-skilled construction workers' (CSSSW) mean ranking scores of these three decent working conditions. 
Table 7: Comparison of site or project managers' (SPM) and skilled and semi-skilled construction workers' (CSSSW) ranking of decent working conditions

\begin{tabular}{|l|c|c|c|c|}
\hline \multicolumn{1}{|c|}{ Decent work condition } & \multicolumn{2}{c|}{ SPM } & \multicolumn{2}{c|}{ CSSSW } \\
\cline { 2 - 5 } & Mean & Rank & Mean & Rank \\
\hline $\begin{array}{l}\text { Provision of adequate occupational health, } \\
\text { safety and well-being requirements on sites }\end{array}$ & 4.864 & 1 & 4.704 & $\mathbf{1}$ \\
\hline $\begin{array}{l}\text { Ensuring the maximum standard working time } \\
\text { (44 hours per week) is adhered to for all workers }\end{array}$ & 4.778 & 2 & 4.167 & 4 \\
\hline $\begin{array}{l}\text { Provision of sufficient personal protective } \\
\text { equipment for workers }\end{array}$ & 4.753 & 3 & 4.593 & 2 \\
\hline $\begin{array}{l}\text { Provision of adequate work-related welfare } \\
\text { facilities on construction sites }\end{array}$ & 4.679 & $\mathbf{4}$ & 4.111 & $\mathbf{5}$ \\
\hline $\begin{array}{l}\text { Satisfactory workplace conditions that enable } \\
\text { enhanced worker efficiency }\end{array}$ & 4.593 & 5 & 4.259 & 3 \\
\hline $\begin{array}{l}\text { Optimum human factor (ergonomics) interventions } \\
\text { on sites (a system of interacting components, } \\
\text { including the worker, both the physical and } \\
\text { organisational work environment, the task and the } \\
\text { workspace) }\end{array}$ & 4.556 & 6 & 4.074 & $\mathbf{6}$ \\
\hline $\begin{array}{l}\text { Appropriate forecasting and planning for various } \\
\text { climatic conditions }\end{array}$ & 4.395 & $\mathbf{7}$ & 4.000 & $\mathbf{7}$ \\
\hline Average MS & 4.660 & & 4.273 & \\
\hline
\end{tabular}

"Provision of sufficient personal protective equipment for workers" was ranked second by site or project managers (MS $=4.593$ ) and third by construction workers (MS $=4.753$ ). Although the condition is significant for both designations, construction workers rated it much higher than the managers did. Construction workers potentially reacted to the contention by the ILO (2018e: 20$)$ that the provision of personal protective equipment as a mere box-ticking exercise is not effective in safeguarding construction workers against site accidents. Thus, workers view this condition as pertinent to their enhancing construction labour productivity on construction sites.

"Provision of adequate work-related welfare facilities on construction sites" was ranked third by managers (MS = 4.259) and fourth by construction workers (MS $=4.679$ ). The results are consistent with these conditions mainly affecting workers in their work on construction sites. Site or project managers are tasked with ensuring that these conditions are conducive for workers; however, they are not directly affected by their status. The Government of Zimbabwe (2013: 281) failed to regulate construction companies regarding the provision of specific standardised work-related welfare facilities, culminating in dismal conditions. However, for workers, Mincks and Johnston (2004: 213) report that the provision of adequate temporary 
facilities related to project requirements has a distinct impact on craftsperson productivity. Owing to this favourable advantage, managers in construction companies are encouraged to afford this decent working condition the attention it deserves. Fundamentally, March (2009: 10) also recognises that productivity losses emanate from employees' attempts to access welfare facilities elsewhere. Such facilities are less prioritised by managers of construction sites.

"Appropriate forecasting and planning for various climatic conditions" was ranked seventh by both managers (MS $=4.00$ ) and construction workers (MS $=4.00)$. Again, the workers have a higher rating of this condition. Since construction projects are undertaken outdoors, they are the ones exposed to these climatic conditions as they go about their tasks. Furthermore, construction workers are also affected in terms of remuneration, especially in situations of inclement weather. Lastly, productivity generally declines when conditions are not optimal (Mincks \& Johnston, 2004: 193). In support of this, Sarode and Shirasath (2012: 2736) guarantee improved employee productivity through the provision of a comfortable work environment, where workers are exposed to a comfortable range of temperature, adequate ventilation and adequate humidity. Hasan et al. (2018: 932) as well as Durdyev and Ismail (2016: 456) reiterate that climatic conditions are one of the riskiest and significant factors that affect labour productivity on construction sites.

\section{Conclusions and recommendations}

The objective of this research was to establish the most significant decent working condition that leads to improved construction skilled workers' productivity. The study also determined the existence of statistical differences, due to the demographics of the respondents (age, gender, designation, educational levels, and experience) concerning the ranking of the same decent working conditions. The results show that the provision of adequate $\mathrm{OSH}$ organisation on sites was the most significant decent working condition that leads to improved construction skilled and semi-skilled workers' productivity. A deliberate OSH drive that incorporates training of site management and workers, including improved compliance to regulations, will lead to productivity gains. Workers are inclined to improve their productivity if the environment in which they are working is safe and protects them against any aspects that can affect their health. Implementation of reward systems associated with OSH behaviour can also have a positive effect in enhancing such conditions within the industry. Beyond these conditions, other 
decent working conditions can be addressed competently within a proposed construction industry bill that is yet to be passed and implemented in Zimbabwe.

Furthermore, the demographics of the respondents show significant differences in their perceptions and insights into the effect the decent working conditions have on productive work on sites, due to the designation and educational levels. Instruction on the construction workers' rights to decent working conditions is paramount, especially on the entitlement to adequate working conditions. On-the-job training that allows these rights to be developed is also pertinent. Firmer collective bargaining by workers and an increased impact of trade unionism within the construction industry is envisaged.

The consensus from both site and project managers and skilled and semi-skilled construction workers is apparent. Despite there being on-site management concerns that must be dealt with by the relevant management structures on sites, it is evident that solutions must also be deliberated beyond the construction sites. This provides construction practitioners with a clear perspective on consequential actions within their contractual, financial, value and risk-management roles in pre-construction, construction and post-construction stages. Sufficient budgets that ensure that such conditions are provided for and the competence to allow for them adequately must be prerequisites for the commencement of construction projects. Furthermore, adjudication of tenders should entail more in-depth inspection and evaluation on sufficient value, financial and riskmanagement considerations of these fundamental conditions. Appropriate planning, monitoring and control will inevitably lead to improving productive work on construction sites, enhancing national productivity and achieving economy within the Zimbabwean construction industry. Conclusively, various construction personnel potentially benefit from this research. Construction, site and project managers benefit through empirical evidence of site conditions that would ensure enhanced productivity on construction sites. Construction workers' welfare is improved through site conditions that safeguard their health and well-being. Beyond the scope of this research, analysis of broader conditions on a larger scale would address specific needs within various geographical areas. 
Moyo, Crafford \& Emuze - Decent working conditions for improved...

\section{References}

Aboagye-Nimo, E. \& Emuze, F. 2017. Construction safety through housekeeping: The Hawthorne effect. In: Emuze, F.A. \& Behm, M. (Eds.). Proceedings of Joint CIB W099 and TG59 International Safety, Health and People in Construction Conference, 11-13 June 2017, Cape Town, South Africa, pp. 285-295.

Abrey, M. \& Smallwood, J.J. 2014. The effects of unsatisfactory working conditions on productivity in the construction industry. Selected papers from Creative Construction Conference 2014. Procedia Engineering, vol. 85, pp. 3-9. https://doi.org/10.1016/j.proeng.2014.10.522

Adhikari, B.R. \& Pandey, B.D. 2011. Decent work and work life quality in Nepal: An observation. Employee Relations, 34(1), pp. 61-79. https://doi.org/10.1108/01425451211183264

Adnan, N.H. \& Ressang, A. 2016. Ergonomics awareness on construction site. [Online]. Available at: <https:// civil.utm. my/wp-content/uploads/2016/12/Ergonomics-Awareness-onConstruction-Site> [Accessed: 20 June 2019].

Akawi, E.J., Musonda, I. \& Pretorius, J. 2017. Identifying the cost drivers for pricing health and safety on construction projects. In: Emuze, F.A. \& Behm, M. (Eds.). Proceedings of Joint CIB W099 and TG59 International Safety, Health and People in Construction Conference, 11-13 June 2017, Cape Town, South Africa, pp. 478-487.

Akintoye, A. \& Main, J. 2007. Collaborative relationships in construction: The UK contractor's perception. Engineering, Construction and Architectural Management, 14(6), pp. 597-617. http://dx.doi. org/10.1108/09699980710829049.

Alvi, M.H. 2016. A manual for selecting sampling techniques in research. Pakistan: University of Karachi, lara University.

Arditi, D., Ayrancioglu, M. \& Shi, J.J. 2005. Worker safety issues in night-time highway construction. Engineering, Construction and Architectural Management, 12(5), pp. 487-501. https://doi. org/10.1108/09699980510627171

Blumberg, B., Cooper, D.R. \& Schindler, P.S. 2008. Business research methods. $2^{\text {nd }}$ edition. Berkshire: McGraw-Hill Higher Education.

Brennan, M.C. \& Cotgrave, A.J. 2014. Sustainable development. Structural Survey, 32(4), pp. 315-330. https://doi.org/10.1108/ SS-02-2014-0010 
Burgess, T.F. \& Heap, J. 2012. Creating a sustainable national index for social, environmental and economic productivity. International Journal of Productivity and Performance Management, 61 (4), pp. 334358. https://doi.org/10.1108/17410401211212634

Chan, A.P.C.,Yam, M.C.H., Chung, J.W.Y.\&Yi,W.2012. Developing a heat stress model for construction workers. Journal of Facilities Management, 10(1), pp. 59-74. https://doi.org/10.1108/14725961211200405

Chaturvedi, S., Thakkar, J.J. \& Shankar, R. 2018. Labour productivity in the construction industry: An evaluation framework for causal relationships. Benchmarking: An International Journal, 25(1), pp. 334-356. https://doi.org/10.1108/BIJ-11-2016-0171

Chigara, B. \& Moyo, T. 2014a. Factors affecting labour productivity on building projects in Zimbabwe. International Journal of Architecture, Engineering and Construction, 3(1), pp. 57-65. https:// doi.org/10.7492/IJAEC.2014.005

Chigara, B. \& Moyo, T. 2014b. Overview of operational and regulatory framework for occupational safety and health management in Zimbabwe's construction industry. In: Emuze, F.A. \& Aigbavbao, C. (Eds.). Proceedings of TG59 'People in Construction' Conference, 6-8 April 2014, Port Elizabeth, South Africa, pp. 150-159.

Chigara, B. \& Smallwood, J.J. 2016. The impact of environmental thermal changes on construction health and safety in Zimbabwe. In: Mwanaumo, E.M., Musonda, I. \& Muleya, F. (Eds.). Proceedings of the $3^{\text {rd }}$ International Conference on Infrastructure Development and Investment Strategies for Africa, 31 August-2 September 2016, Livingstone, Zambia, pp. 290-302.

Chileshe, N.\&Haupt,T.C.2010. The effectofage on thejobsatisfaction of construction workers. Journal of Engineering, Design and Technology, 8(1), pp. 107-118. https://doi.org/10.1108/17260531011034682

Chileshe, N. \& Yirenkyi-Fianko, A.B. 2012. An evaluation of risk factors impacting construction projects in Ghana. Journal of Engineering, Design and Technology, 10(3), pp. 306-329. https://doi. org/10.1 108/17260531211274693

Chinyere, I.N. 2014. Influence of workstation and work posture ergonomics on job satisfaction of librarians in the Federal and State University Libraries in Southern Nigeria. Journal of Humanities and Social Science, 19(9), pp. 78-84. https://doi.org/10.9790/0837-19947884 
Moyo, Crafford \& Emuze • Decent working conditions for improved...

CIDB (Construction Industry Development Board). 2015. Labour and work conditions in the South African construction industry: Status and recommendations. [Online]. Available at: <www.cidb.org.za/ publications/Documents/Labour and Work> [Accessed: 20 June 2019].

CIOB (Chartered Institute of Building). 2016. Productivity in construction: Creating a framework for the industry to thrive. [Online]. Available at: <https://policy.ciob.org/wp-content/.../ClOB-Productivity-report2016-v4_single.pdf.> [Accessed: 20 June 2019].

Coupaud, M. 2017. Determinants of health at work in the EU15: Elaboration of synthetic indicators of working conditions and their impacts on the physical and mental health of workers. International Journal of Manpower, 38(1), pp. 93-126. https://doi.org/10.1108/ IJM-02-2016-0040

De Silva, N.P. \& Wimalaratne, L.I. 2012. OSH management framework for workers at construction sites in Sri Lanka. Engineering, Construction and Architectural Management, 19(4), pp. 369-392. https://doi. org/10.1108/09699981211237094

Durdyev, S. \& Ismail, S. 2016. On-site construction productivity in Malaysian infrastructure projects. Structural Survey, 34(4/5), pp. 446462. https://doi.org/10.1108/SS-12-2015-0058

Durdyev, S. \& Mbachu, J. 2017. Key constraints to labour productivity in residential building projects: Evidence from Cambodia. International Journal of Construction Management, 18(5), pp. 385-393. https://doi. org/10.1080/15623599.2017.1326301

Eaves, S., Gyi, D. \& Gibb, A. 2013. Building healthy construction workers by better workplace design: Understanding the context. In: Smith, S.D. \& Ahiaga-Dagbui, D.D. (Eds.). Proceedings of the $29^{\text {th }}$ Annual Association of Researchers in Construction Management (ARCOM) Conference, 2-4 September 2013, Reading, UK, pp. 101-109.

Emuze, F. 2017. The human contribution to unsafe construction acts and conditions in the central region of South Africa. In: Chan, P.W. \& Neilson, C.J. (Eds.). Proceedings of the $33^{\text {rd }}$ Annual Association of Researchers in Construction Management (ARCOM) Conference, 4-6 September 2017, Fitzwilliam College, Cambridge, UK, pp. 330-339. https://doi.org/10.1108/JEDT-08-2010-0057

Emuze, F. \& Smallwood, J.J. 2014. Collaborative working in South African construction: Contractors' perspectives. Journal of Engineering, Design and Technology, 12(3), pp. 294-306. 
Fernandes, K., Hyde, A., Ives, S., Fliescher, S., Evoy, T. \& Van Marrum, K. 2012. A comparative study of work values between Generation X and Generation Y. University of Guelph. [Online]. Available at: <www. http//:propertibazar.com/article/issn-2349-5677-special> [Accessed: 20 June 2019].

Field, A. 2014. Discovering statistics using IBM SPSS statistics. $4^{\text {th }}$ edition. Los Angeles, CA: Sage Publications.

Forbes, L.H. \& Ahmed, S.M. 2011. Modern construction: Lean project delivery and integrated practices. Boca Raton, FL: CRC Press. https:// doi.org/10.1201/b10260

Galpin, T., Whittington, J.L. \& Bell, G. 2015. Is your sustainability strategy sustainable? Creating a culture of sustainability. Corporate Governance, 15(1), pp. 1-17. https://doi.org/10.1108/ CG-01-2013-0004

George, D. \& Mallery, P. 2003. SPSS for Windows step-by-step: A simple guide and reference. 11.0 update. $4^{\text {th }}$ edition. Boston, NY: Allyn \& Bacon.

Ghasemi, A. \& Zahediasl, S. 2012. Normality tests for statistical analysis: A guide for non-statisticians. International Journal of Endocrinology Metabolism, 10(2), pp. 486-489. https://doi.org/10.5812/ijem.3505

Goldswain, C. \& Smallwood, J.J. 2013. Key inputs into a designing for construction health, safety, and ergonomics model in South Africa. In: Smith, S.D. \& Ahiaga-Dagbui, D.D. (Eds.). Proceedings of the $29^{\text {th }}$ Annual Association of Researchers in Construction Management (ARCOM) Conference, 2-4 September 2013, Reading, UK, pp. 359-367.

Gong, J., Borcherding, J.D. \& Caldas, C.H. 2011 . Effectiveness of craft time utilization in construction projects. Construction Management and Economics, 29(7), pp. 737-751. https://doi.org/10.1080/0144619 3.2011 .595013

Government of Zimbabwe. 1997. Public Health Act of 1997. Chapter 15:09. [Online]. Available at: <www.parlzim.gov.zw/component/k2/ public-health> [Accessed: 20 June 2019].

Government of Zimbabwe. 2001. Factories and Works Act 22 of 2001. Chapter 14:08. [Online]. Available at: <http://www.parlzim.gov.zw/ acts-list> [Accessed: 20 June 2019].

Government of Zimbabwe. 2002. Labour Act 13 of 2002. Chapter 28:01. [Online]. Available at: <http://www.parlzim.gov.zw/acts-list/ labour-act-28-01> [Accessed: 20 June 2019]. 
Moyo, Crafford \& Emuze - Decent working conditions for improved...

Government of Zimbabwe. 2013. Collective Bargaining Agreement. Statutory Instrument 45 of 2013 registered in terms of section 79 of the Labour Act. Harare, Zimbabwe: Government Printers \& Stationaries.

Government of Zimbabwe. 2014. Skills training and the employment situation of young people in Zimbabwe. A report on the analysis of the technical and vocational education and training (Tvet) and the employment situation of young people in Zimbabwe. Harare, Zimbabwe: Government Printers \& Stationaries.

Gray, D.E. 2009. Doing research in the real world. $2^{\text {nd }}$ edition. London: Sage Publications.

Hare, B. \& Cameron, I. 2012. Health and safety gateways for construction project planning. Engineering, Construction and Architectural Management, 19(2), pp. 192-204. https://doi. org/10.1108/09699981211206115

Hartrich, S. 2018. Can we create better jobs in Africa's booming construction sector? Looking to market systems analyses to point us in the right direction. International Labour Organization. [Online]. Available at: <https://www.ilo.org/empent/Projects/the-lab/WCMS_652332/> [Accessed: 20 June 2019].

Hasan, A., Baroudi, B., Elmualim, A. \& Rameezdeen, R. 2018. Factors affecting construction productivity: A 30-year systematic review. Engineering, Construction and Architectural Management, 25(7), pp. 916-937. https://doi.org/10.1108/ECAM-02-2017-0035

Horman, M.J. \& Kenley, R. 2005. Quantifying levels of wasted time in construction with meta-analysis. Journal of Construction Engineering and Management, 131(1), pp. 52-61. https://doi.org/10.1061/ (ASCE)0733-9364(2005) 131:1(52)

ILO (International Labour Organization). 2006. Decent work: Objectives and strategies. Geneva: International Institute of Labour Studies. [Online]. Available at: <https://www.ilo.org/wcmsp5/groups/ public/---dgreports/---inst/> [Accessed: 20 June 2019].

ILO (International Labour Organization). 2009. Moving from precarious employment to decent work. Geneva: Global Union Research Network. [Online]. Available at: <www.ilo.org/wcmsp5/ groups/public/@ed_dialogue/@actrav/wcms_179787.pdf> [Accessed: 20 June 2019]. 
ILO (International Labour Organization). 2013. Decent work indicators: Guidelines for producers and users of statistical and legal framework indicators. Geneva: ILO [Online]. Available at: <www.lo.org/wcmsp5/ groups/public/dgreports/wcms_229374.pdf> [Accessed: 20 June 2019].

ILO (International Labour Organization). 2018a. Decent work and the sustainable development goals: A guidebook on SDG labour market indicators. Geneva: Department of Statistics (STATISTICS), ILO. [Online]. Available at: <https://www.ilo.org/ WCMS_647109/> [Accessed: 20 June 2019].

ILO (International Labour Organization). 2018b. The impact of social dialogue and collective bargaining on working conditions in SMEs. Geneva: ILO, Enterprises. [Online]. Available at: <https://www.ilo. org/WCMS_651378/> [Accessed: 20 June 2019].

ILO (International Labour Organization). 2018c. World employment social outlook 2018: Greening with jobs. Geneva: ILO. [Online]. Available at: <https://www.ilo.org/WCMS_628654/> [Accessed: 20 June 2019].

ILO (International Labour Organization). 2018d. Back to the future. Challenges and opportunities for the future of work addressed in ILO sectoral meetings since 2010. Geneva: ILO. [Online]. Available at: <https://www.ilo.org/WCMS_628793/> [Accessed: 20 June 2019].

ILO (International Labour Organization). 2018e. Laying a foundation for better working conditions: A market systems analysis in Rwanda's building construction sector. Geneva: ILO. [Online]. Available at: <https://www.ilo.org/WCMS_644796/> [Accessed: 20 June 2019].

Jang, H., Kim, K., Kim, J. \& Kim, J. 201 1. Labour productivity model for reinforced concrete construction projects. Construction Innovation, 11 (1), pp. 92-113. https://doi.org/10.1108/14714171111104655

Jimoh, R.A., Oyewobi, L.O., Adamu, A.N. \& Bajere, P.A. 2016. Women professionals' participation in the Nigerian construction industry: Finding voice for the voiceless. Organization, Technology and Management in Construction, vol. 8, pp.1429-1436. https://doi. org/10.1515/otmcj-2016-0005

Johnson, T. \& Owens, L. 2003. Survey response rate reporting in the professional literature. American Association for Public Opinion Research. [Online]. Available at: <www.srl.uic.edu/publist/ Conference/rr_reporting.pdf> [Accessed: 20 June 2019].

Jones, K. 2018. Four major challenges facing the construction industry. Constructconnect. [Online]. Available at: <www.constructconnect. com/blog/operating-insights/> [Accessed: 20 June 2019]. 
Kattenbach, R., Demerouti, E. \& Nachreiner, R. 2010. Flexible working times: Effects on employees' exhaustion, work-non work conflict and job performance. Career Development International, 15(3), pp. 279-295. https://doi.org/10.1108/13620431011053749

Khan, A. \& Sandhu, M. 2016. Benchmarking national culture and decent work practice indicators in project-based industry: Lessons from United Arab Emirates. Benchmarking: An International Journal, 23(3), pp. 490-518. https://doi.org/10.1108/BIJ-02-2014-0015

Kocer, R.G. 2014. Can productivity be socially embedded? Reflections on some productivity measures of 2000s. International Journal of Productivity and Performance Management, 63(3), pp. 354-369. https://doi.org/10.1108/IJPPM-04-2013-0063

Kothari, C.R. 2009. Research methodology: Methods and techniques. $2^{\text {nd }}$ revised edition. New Delhi: New Age International Publishers.

Krejcie, R.V. \& Morgan, D.W. 1970. Determining sample size for research activities. Educational and Psychological Measurement, 30(3), pp. 607-610. https://doi.org/10.1177/001316447003000308

Langston, C., Song, Y. \& Purdey, B. 2008. Perceived conditions of workers in different organizational settings. Facilities, 26(1/2), pp. 54-67. https://doi.org/10.1 108/02632770810840309

Lill, I. 2008. Sustainable management of construction labour. In: Proceedings of the $25^{\text {th }}$ International Symposium on Automation and Robotics in Construction, 26-29 June, Vilnius Gediminas University, Lithuania. https://doi.org/10.3846/isarc.20080626.864

Lingard, H., Cooke, T. \& Blismas, N. 2011. Co-workers' response to occupational health and safety: An overlooked dimension of group-level safety climate in the construction industry? Engineering, Construction and Architectural Management, 18(2), pp. 159-175. https://doi.org/10.1108/09699981111111139

March, C. 2009. Operations management for construction. New York: Taylor \& Francis. https://doi.org/10.4324/9780203928035

Mhlanga, P. 2017. Construction industry shrinks. The Financial Gazette, 23 February 2017, p. 3.

Mincks, W.R. \& Johnston, H. 2004. Construction jobsite management. $2^{\text {nd }}$ edition. New York: Delmar Learning.

Moyo, T., Mangore, E. \& Chigara, B. 2014. Work measurement techniques utilized by the building industry in the Midlands province 
of Zimbabwe. International Journal of Sustainable Construction Engineering \& Technology, 5(1), pp. 42-52.

Naoum, S.G. 2013. Dissertation research and writing for construction students. $3^{\text {rd }}$ edition. Oxford: Butterworth-Heinemann. https://doi. org/10.4324/9780203720561

Naoum, S.G. 2016. Factors influencing labor productivity on construction sites: A state of-the-art literature review and a survey. International Journal of Productivity and Performance Management, 65(3), pp. 401-421. https://doi.org/10.1108/IJPPM-03-2015-0045

Nkado, R. \& Meyer, T. 2001. Competencies of a professional quantity surveyor: A South African perspective. Construction Management and Economics, 19(5), pp. 481-491. https://doi.org/10.1080/0144619 3.2001 .10383092

Nunez, I. \& Villanueva, M. 2011. Safety capital: The management of organizational knowledge on occupational health and safety. Journal of Workplace Learning, 23(1), pp. 56-71. https://doi. org/10.1108/136656211111097254

Obiozo, R.N. \& Smallwood, J.J. 2014. The intelligent construction workplace: The exceptional credential of the biophilic design concept of the worksite. In: Emuze, F.A. \& Aigbavbao, C. (Eds.). Proceedings of the TG59 'People in Construction' Conference, 6-8 April 2014, Port Elizabeth, South Africa, pp. 139-146.

Obiozo, R.N. \& Smallwood, J.J. 2015. Biophilic construction site model: Enhancing the motivational and humanistic value of the green construction site. Journal of Construction Engineering and Management. [Online]. Available at: <https://ascelibrary.org/toc/ jcemd4/141/3> [Accessed: 20 June 2019]. https://doi.org/10.1061/ (ASCE)CO.1943-7862.0000941

Occupational Safety and Health Administration. 2002. Job hazard analysis. U.S. Department of Labor. [Online]. Available at: <www. osha.gov/Publications/osha3071.pdf> [Accessed: 20 June 2019].

Osei-Kyei, R. \& Chan, A.P.C. 2017 Empirical comparison of critical success factors for public-private partnerships in developing and developed countries: A case of Ghana and Hong Kong. Engineering, Construction and Architectural Management, 24(6), pp. 1222-1245. https://doi.org/10.1108/ECAM-06-2016-0144 
Oswald, D., Sherratt, F. \& Smith, S.D. 2017. An investigation into a health and safety rewards system on a large construction project. In: Chan, P.W. \& Neilson, C.J. (Eds.). Proceedings of the 33 $3^{\text {rd }}$ Annual Association of Researchers in Construction Management (ARCOM) Conference, 4-6 September 2017, Fitzwilliam College, Cambridge, UK, pp. 370-379.

Pallant, J. 2013. SPSS survival manual: A step-by-step guide to data analysis using IBM SPSS. $5^{\text {th }}$ edition. Crows Nest, Australia: Allen and Unwin.

Presley,A.\&Meade,L.2010.Benchmarking forsustainability:Anapplication to the sustainable construction industry. Benchmarking: An International Journal, 17(3), pp. 435-451. https://doi.org/10.1 108/14635771080001426

Reese, C.D. 2016. Occupational health and safety management: A practical approach. Boca Raton, FL: CRC Press.

Salaj, A.T., Baricic, A. \& Maamari, B. 2017. How economic crisis affects workplace conditions and occupational health. In: Emuze, F.A. \& Behm, M. (Eds.). Proceedings of the Joint CIB W099 and TG59 International Safety, Health and People in Construction Conference, 11-13 June 2017, Cape Town, South Africa, pp. 510-523.

Sarode, A.P. \& Shirsath, M. 2012. The factors affecting employee work environment and its relation with employee productivity. International Journal of Science and Research, 3(11), pp. 2735-2737.

Schroer, W.J. 2008. Generations X, Y, Z and others. The Journal of the Household Goods Forwarders Association of America Inc., XL (March/April). [Online]. Available at: <https://iam.files.cms-plus.com/ newimages/portalpdfs/2008_03_04.pdf> [Accessed: 20 June 2019].

Sherratt, F. \& Sherratt, S. 2017. The road to hell: Worker health, safety and well-being within UK corporate social responsibility practices. In: Chan, P.W. \& Neilson, C.J. (Eds.). Proceedings of the $33^{\text {rd }}$ Annual Association of Researchers in Construction Management (ARCOM) Conference, 4-6 September 2017, Fitzwilliam College, Cambridge, UK, pp. 389-398.

Smallwood, J.J. \& Haupt, T.C. 2009. Construction ergonomics: Perspectives of female and male production workers. In: Dainty, A.R.J. (Ed.). Proceedings of the $25^{\text {th }}$ Annual Association of Researchers in Construction Management (ARCOM) Conference, 7-9 September 2009, Nottingham, UK, 2, pp. 1263-1271. 
Smith, M. \& Zagelmeyer, S. 2010. Working time management and SME performance in Europe. International Journal of Manpower, 31 (4), pp. 392-409. https://doi.org/10.1108/01437721011056994

Taderera, H. 2012. Occupational health and safety management systems: Institutional and regulatory frameworks in Zimbabwe. International Journal of Human Resource Studies, 2(4), pp. 99-117. https://doi.org/10.5296/ijhrs.v2i4.2149

Taherdoost, H. 2016. Validity and reliability of the research instrument: How to test the validation of a questionnaire/survey in a research. International Journal of Academic Research in Management, 5(3), pp. 28-36. https://doi.org/10.2139/ssrn.3205040

Tolbize, A. 2008. Generational differences in the workplace. Research and Training Center on Community Living, University of Minnesota. [Online]. Available at: <https://rtc.umn.edu/docs/2_18_Gen_diff_ workplace.pdf> [Accessed: 20 June 2019].

Townsend, K., Lingard, H., Bradley, L. \& Brown, K. 201 1. Working time alterations within the Australian construction industry. Personnel Review, 40(1), pp. 70-86. https://doi.org/10.1108/00483481111095528

Wadick, P. 2010. Safety culture among subcontractors in the domestic housing construction industry. Structural Survey, 28(2), pp. 108-120. https://doi.org/10.1108/02630801011044217

Wegner, T. 2012. Applied business statistics methods and excel-based applications solutions manual. $4^{\text {th }}$ edition. Cape Town: Juta.

Yelland, P.M. 2010. An introduction to correspondence analysis. The Mathematica Journal, vol.12, pp. 1-23. https://doi.org/10.3888/ tmj. 12-4 